\title{
Research on Customer Geographic Proximity and Inventory Management-Empirical Evidence from Chinese Manufacturing Listed Companies
}

\author{
Xiaoting Hu \\ School of Management, Jinan University, Guangzhou, China \\ Email: 13760843786@139.com
}

How to cite this paper: Hu, X.T. (2019) Research on Customer Geographic Proximity and Inventory Management-Empirical Evidence from Chinese Manufacturing Listed Companies. American Journal of Industrial and Business Management, 9, 1-10.

https://doi.org/10.4236/ajibm.2019.91001

Received: December 7, 2018

Accepted: January 4, 2019

Published: January 7, 2019

Copyright $\odot 2019$ by author and Scientific Research Publishing Inc. This work is licensed under the Creative Commons Attribution International License (CC BY 4.0).

http://creativecommons.org/licenses/by/4.0/

\begin{abstract}
Using the hand collected data of the top five clients of manufacturing enterprises in China, this paper examines the effect of customer geographic proximity on the inventory management level of manufacturing enterprises. The results show that there is a positive relation between the geographic proximity and inventory management level: the greater the geography proximity of customers, the lower the proportion of inventory, the higher the inventory turnover rate. This paper not only contributes to the literature on the factors affecting the level of inventory management and the supply chain management, but also provides reference on how the manufacturing enterprises can maintain the relationship with customers better, and improve inventory management efficiency.
\end{abstract}

\section{Keywords}

Geographic Proximity, Inventory Management Efficiency, Supply chain

\section{Introduction}

With the continuous advancement of global economic integration in the 1980s, and the continuous evolution of production and operation management theory, supply chain management has gradually emerged and been promoted. However, with the increasing complexity of the supply chain, how to manage and reduce the risks associated with the supply chain has become an important issue for corporate executives [1]. As the basis for the survival and development of manufacturing enterprises, inventory has a profound impact on enterprises. Howev- 
er, it is not uncommon for companies to cause financial crisis due to poor inventory management, leading to business difficulties or even bankruptcy. In view of the importance of inventory management in enterprise risk management, a large number of scholars have studied how to carry out inventory management efficiently and the influencing factors of inventory management, such as the economic order quantity (EOQ), the $\mathrm{ABC}$ classification, the material requirement plan (MRP), Just In Time, Enterprise Resource Planning (ERP), Supply Chain Management System (SCM), etc. In terms of the influencing factors of inventory management, domestic and foreign scholars believe that at the macro level, interest rate fluctuations [2], regional institutional environment [3], transportation facilities construction [4], inflation expectations [5]; at micro scale: company size [6], sales growth rate [7], lean production [8] and other factors affect inventory management. Investigating the influencing factors of inventory management at the micro level can not only think about the enterprise itself, but also consider the relationship between enterprises and customers. The relationship between enterprises and customers includes not only customer concentration, but also customer geographic proximity, because customer geographic proximity can affect the company's inventory management through information exchange and cooperation. A large number of scholars have examined the influence of the choice of the number of main customers on the enterprises from the perspective of customer concentration. However, the research on the influence of customer geographical location on the financial and accounting decisions of enterprises is not rich enough.

The so-called customer geographic proximity, refers to the degree of geographical similarity between the main customer and the enterprise, such as whether they belongs to a province, city or county [9]. In theory, customer geographic proximity can affect the level of inventory management through information exchange and cooperation. When the geographical proximity of a enterprise and its customers is high, enterprises can use "local advantages" to collect more private information about customer needs and volatility, so as to arrange procurement and production more effectively, and improve inventory management. Based on the above research background, this paper uses the manually collected data of the top five customers of China's manufacturing enterprises to examine the impact of customer geographic proximity on inventory management level of manufacturing enterprises. The results show that there is a positive relation between the geographic proximity and inventory management level: the greater the geography proximity of customers, the lower the proportion of inventory, the higher the inventory turnover rate.

The contributions of this paper are as follows:

Most of the previous literatures focused on the interest rate fluctuation, regional institutional environment, inflation expectation, company size, sales growth rate and lean production. This paper studies the influence of customer geographic proximity on enterprise's inventory management level, which provides a new perspective for the study of inventory influencing factors. 
In the existing literature on the relationship between customer and supplier, the academic community mostly consider the relationship between profitability [10], earnings management [11], audit quality [12], bank loans [13], cost of capital [14] and tax avoidance [15] from the perspective of customer concentration. This paper studies the influence factors of inventory management based on the customer geographic proximity, and extends from the single dimension of customer concentration to the dimension of geographical location.

The rest of this paper is arranged as follows: the second part is literature review and research hypothesis; the third part is the research design of this paper; the fourth part is the empirical results; the fifth part is the conclusions.

\section{Literature Review and Research Hypothesis}

Geographical distance can affect the level of inventory management through information exchange channels. On the one hand, geographical proximity is conducive to the exchange of private information, reducing the degree of information asymmetry and transaction costs. For example, Knechel believe that geographical proximity make it easier for auditors to communicate, understand and supervise the information of the audited entity [16]. This "local advantage" can lead to lower audit risk and higher audit quality. Venture capital has obvious local preference characteristics, which is manifested by the geographical distance between venture capital and the new enterprise. The smaller the amount of venture capital invested in the new enterprise, the later the time is, and the lower the possibility of participating in corporate governance after investment [17]. On the other hand, the low geographical proximity leads to less private information exchange and a greater degree of information asymmetry, which has an adverse impact on company decision-making. For example, John found that remote company positions increase the cost of monitoring shareholders' management decisions, so companies are willing to pay higher dividends in order to mitigate agency conflicts [18]. The farther the distance between accounting firms participating in integration is, the more difficult it is to integrate and the worse the integration effect [19]. Most of the above literatures are based on the same starting point, that is, the information advantage and knowledge spillover effect brought by the local advantage. Based on the above literature, this paper investigates the influence of customer geographic proximity on inventory management level of manufacturing enterprises in China.

Based on the importance of inventory management to macro-economy and micro-enterprises, a large number of scholars have studied the factors that affect the level of inventory management. At the macro level, Rao study the impact of inflation expectations on corporate inventory adjustment behavior of enterprises, and concluded that enterprises adjust inventory investment through inflation expectations, which is manifested as: when the expected inflation rate rises, companies will increase their investment in inventory accordingly [5]. The results of [3] show that the company's inventory turnover rate in the developed 
areas is faster than that of the underdeveloped areas, which further indicates that the development of the institutional basis has a significant impact on the efficiency of inventory management.

At the micro level, Shan collected business data from 1286 listed companies listed on the Shanghai Stock Exchange and the Shenzhen Stock Exchange, and found that the size of the company has a significant impact on the inventory management level of Chinese companies [6]. As in [7], Zhao examined the current situation of inventory management of domestic retail enterprises between 1996 and 2005, and found that the inventory turnover rate was significantly positively correlated with the proportion of fixed assets and sales scale. Moreover, it is said that companies with widely used lean production have higher inventory turnover rates [8].

In theory, there is a positive correlation between customer geographic proximity and enterprise inventory management level. On the one hand, enterprises need to consider customer demand and its volatility, transportation, inventory holding cost and other factors to determine the order quantity and holdings of inventory [20] [21]. Companies have an incentive to collect information about customer needs and their volatility, especially private information, in order to arrange procurement and production. When the geographical proximity between the enterprise and its main customers is high, enterprises can use their local advantages to obtain more private information about their customers' needs and to gain a better understanding of the use of their products by their customers. We can arrange or adjust production timely according to customers' demand, improve inventory turnover, and minimize inventory holding cost [22]. On the other hand, the local government's consideration of increasing employment and increasing economic growth will also promote stable and reliable partnership between companies and local customers [23]. Stable and reliable customer relationships help increase the company's proprietary investment in major customers, promote synergy with customers, increase the frequency and depth of information exchange between companies and customers, and thus more effectively manage inventory [24]. Based on the above reasons, this paper proposes the hypothesis:

The higher the geographical proximity between the enterprise and the major customers, the higher the enterprise inventory management level.

\section{Research Design}

\subsection{Sample Selection}

This paper takes the manufacturing enterprises listed and traded on the Shanghai and Shenzhen Stock Exchanges in 2009-2016 as the research sample. This paper only studies manufacturing enterprises, because for manufacturing enterprises, inventory has a large proportion in their assets, which has an important impact on the business development of manufacturing enterprises. Therefore, this paper manually collected the name, geographical location (province or city) 
of the top five customers of listed manufacturing enterprises until 2016, and the proportion of purchasing in the enterprises, and so on. The top five customers refer to the top 5 customers with the largest transaction volume among the customers who purchase the enterprise products. All financial data of the sample company comes from the CSMAR database. This paper downloads the annual financial statements of each listed company from Cninfo.com, and finds the top five customer names of each company from the annual financial statements. Find the geographic location on the Tianyancha website based on the top five customer names of each company.

In the process of sample selection, the following sample observations are excluded: 1) incomplete financial data and sample observations that cannot calculate geographical proximity; 2) sample observations with asset-liability ratio greater than 1;3) Sample observations with growth rate greater than 100; (4) Sample observations with an inventory turnover ratio greater than 1000. Finally, 3521 sample observations were obtained. In order to eliminate the influence of outliers, this paper adjusts the processing of all continuous variables by up and down $1 \%$ (winsorize).

\subsection{Variable Definition}

This paper investigates whether the geographical proximity of customers will affect the inventory management level of China's manufacturing enterprises. The dependent variables are the inventory ratio of enterprises and inventory turnover (Inventory and Inturnover), and the independent variables are customer geographical proximity (CGP1 and CGP2). The construction method of specific indicators (CGP1) is as follows [9] [25]: where $I_{j, \text { local }}$ is an indicator variable with $I_{j \text {,local }}=1$ if customer $j$ is located in the same geographical area (i.e., city) as firm $i$ and $I_{j, \text { local }}=0$ otherwise. For a firm with n major customers, its geographical proximity (CGP1) is the weighted average of all customers' indicator variables that are equal to one (zero) if the customer and the firm are (are not) in the same city. The weight is each customers' percentage share of the firm's selling to all of the $n$ customers. We use the weighted average to account for the relative importance of individual customers in terms of their procurement from the firm. The calculation of customer geographic similarity (CGP2) is basically the same as that of CGP1, except the region is changed from city to province.

The following variables are controlled in the model: Ownership, Customer Concentration (CHHI), Gross Profit (Gross), Growth (Growth), Sales Volatility (Sales Volatility), Capital Intensity (CI), Listing (Firmage), Leverage, Profitability (ROA), Profit (Loss), Company Size, Industry and Year [2] [4] [26] [27] [28]. The definition of each variable is shown in Table 1.

\subsection{Equations}

To test hypothesis, this paper have constructed the following model to test the impact of customer geographic proximity on the inventory management level of 
Table 1. Variable definition.

\begin{tabular}{|c|c|}
\hline Variable & Definition \\
\hline Inventory & $\begin{array}{l}\text { The average of the net inventory at the end of the year and at the beginning of } \\
\text { the year/total assets at the end of the year }\end{array}$ \\
\hline Inturnover & $\begin{array}{l}\text { Main business cost at the end of the year/(year-end inventory + beginning } \\
\text { stock)/2 }\end{array}$ \\
\hline CGP1 & Customer geographic proximity calculated by city \\
\hline CGP2 & Customer geographic proximity calculated by province \\
\hline Ownership & $=1$ if firm is a state-owned enterprise; $=0$ otherwise \\
\hline $\mathrm{CHHI}$ & $\begin{array}{l}\text { the Herfinda Index, calculated by the company's sales of the top five } \\
\text { customers, }\end{array}$ \\
\hline Gross & $\begin{array}{l}\text { (Main business income of the year - main business cost of the year)/main } \\
\text { business income of the year }\end{array}$ \\
\hline Growth & $\begin{array}{l}\text { (Main business income of the year - main business income of the previous } \\
\text { year)/main business income of the previous year }\end{array}$ \\
\hline Sales volatility & $\begin{array}{l}\text { The standard deviation of company's main business income in the current year } \\
\text { and the previous two years divided by the average total assets }\end{array}$ \\
\hline $\mathrm{CI}$ & The company's fixed assets/the main business income of the year \\
\hline Firm age & $\begin{array}{l}\text { The natural log of the number of years since the firm gets listed in the stock } \\
\text { market plus } 1 \text { (calculated on a monthly basis) }\end{array}$ \\
\hline Leverage & $\begin{array}{l}\text { Total liabilities of the company at the end of the year/ total assets at the end of } \\
\text { the year }\end{array}$ \\
\hline ROA & The company's net profit for the year/total assets at the end of the year \\
\hline Loss & If the company has a loss in the current year, take 1 ; otherwise it is 0 \\
\hline Size & The natural logarithm of the total assets of the company at the end of the year \\
\hline
\end{tabular}

China's manufacturing enterprises [2] [4] [26] [27] [28]. This paper uses the company-level fixed-effects model to examine the impact of customer geography on the level of inventory management.

Inventoryor Inturnover $=\beta_{0}+\beta_{1} \mathrm{CGP}+\beta_{2}$ Ownership $+\beta_{3} \mathrm{CHHI}+\beta_{4}$ Gross $+\beta_{5}$ Growth

$$
\begin{aligned}
& +\beta_{6} \text { Salesvolatility }+\beta_{7} \mathrm{CI}+\beta_{8} \text { Firmage }+\beta_{9} \text { Leverage } \\
& +\beta_{10} \text { ROA }+\beta_{11} \text { Loss }+\beta_{12} \text { Size }+ \text { Firm }+ \text { Year }+\varepsilon
\end{aligned}
$$

In the model, the dependent variable is the inventory management level, which includes the inventory of the enterprise and the inventory turnover rate (Inturnover). The independent variables in this paper are customer geographic proximity (CGP1 and CGP2). The so-called customer geographic proximity, refers to the degree of geographical similarity between the main customer and the enterprise, such as whether they belongs to a province, city or county. As in [26], other variables concluded in the model can affect the dependent variable. In addition, $\beta_{0}$ represents a constant term, and $\beta_{1}-\beta_{12}$ represents a coefficient. If the hypothesis 1 is true, the coefficient $\beta_{1}$ of the CGP in the model will be significantly negative (positive) when Inventory (Inturnover) is the dependent variable. 


\section{Empirical Results}

Column (1) - Column (4) of Table 2 lists the results for hypothesis 1 . The coefficient of CGP1 in the first column of the results is -0.0176 , which is significant at

Table 2. Result for hypothesis 1.

\begin{tabular}{|c|c|c|c|c|}
\hline & Inventory & lnturnover & Inventory & lnturnover \\
\hline & (1) & (2) & (3) & (4) \\
\hline \multirow[t]{2}{*}{ Constant } & $0.7159^{* * *}$ & $14.0242^{\star *}$ & $0.7154^{* * *}$ & $14.4686^{* *}$ \\
\hline & $(4.85)$ & $(2.40)$ & $(4.87)$ & $(2.52)$ \\
\hline \multirow[t]{2}{*}{ CGP1 } & $-0.0176^{* *}$ & $1.0731^{\star * \star}$ & & \\
\hline & $(-2.12)$ & $(2.93)$ & & \\
\hline \multirow[t]{2}{*}{ CGP2 } & & & $-0.0225^{\star * *}$ & $0.7711^{* * *}$ \\
\hline & & & $(-2.75)$ & $(2.73)$ \\
\hline \multirow[t]{2}{*}{ Ownership } & 0.0181 & $-1.2221^{\star *}$ & 0.0185 & $-1.2325^{\star *}$ \\
\hline & (1.47) & $(-2.04)$ & $(1.52)$ & $(-2.06)$ \\
\hline \multirow[t]{2}{*}{ CHHI } & -0.0160 & $2.1642^{*}$ & -0.0167 & $2.2839^{*}$ \\
\hline & $(-0.38)$ & (1.83) & $(-0.40)$ & $(1.90)$ \\
\hline \multirow[t]{2}{*}{ Gross } & $-0.0979^{* * *}$ & $-5.4127^{\star * *}$ & $-0.1023^{\star * *}$ & $-5.2953^{* * *}$ \\
\hline & $(-2.90)$ & $(-3.79)$ & $(-3.03)$ & $(-3.73)$ \\
\hline \multirow[t]{2}{*}{ Growth } & -0.0012 & $1.0959^{* * *}$ & -0.0012 & $1.0904^{\star * *}$ \\
\hline & $(-0.37)$ & $(6.21)$ & $(-0.38)$ & $(6.19)$ \\
\hline \multirow[t]{2}{*}{ Sales volatility } & $-0.0188^{\star *}$ & $1.9731^{\star *}$ & $-0.0189^{* *}$ & $1.9469^{* *}$ \\
\hline & $(-2.05)$ & $(2.23)$ & $(-2.06)$ & (2.19) \\
\hline \multirow[t]{2}{*}{$\mathrm{CI}$} & $-0.0422^{\star * *}$ & $-0.9713^{* * *}$ & $-0.0428^{\star * *}$ & $-0.9412^{* * *}$ \\
\hline & $(-4.30)$ & $(-2.65)$ & $(-4.39)$ & $(-2.60)$ \\
\hline \multirow[t]{2}{*}{ Firm age } & $0.0361^{\star * *}$ & -0.3527 & $0.0367^{\star * *}$ & -0.3711 \\
\hline & $(4.11)$ & $(-1.03)$ & $(4.20)$ & $(-1.08)$ \\
\hline \multirow[t]{2}{*}{ leverage } & $0.0603^{* * *}$ & -1.0479 & $0.0605^{* * *}$ & -1.0385 \\
\hline & $(3.23)$ & $(-1.58)$ & $(3.25)$ & $(-1.56)$ \\
\hline \multirow[t]{2}{*}{$\mathrm{ROA}$} & 0.0218 & 1.8066 & 0.0236 & 1.7970 \\
\hline & $(0.48)$ & $(1.00)$ & $(0.52)$ & $(1.00)$ \\
\hline \multirow[t]{2}{*}{ Loss } & 0.0041 & -0.0163 & 0.0041 & -0.0116 \\
\hline & $(1.07)$ & $(-0.10)$ & $(1.07)$ & $(-0.07)$ \\
\hline \multirow[t]{2}{*}{ Size } & $-0.0304^{* * *}$ & -0.3253 & $-0.0302^{\star * *}$ & -0.3461 \\
\hline & $(-4.56)$ & $(-1.25)$ & $(-4.55)$ & $(-1.35)$ \\
\hline Firm & Control & Control & Control & Control \\
\hline Year & Control & Control & Control & Control \\
\hline $\mathrm{N}$ & 3521 & 3521 & 3521 & 3521 \\
\hline Adjusted R2 & 0.169 & 0.152 & 0.174 & 0.151 \\
\hline
\end{tabular}


the level of 5\%, indicating that the geographical proximity of the customers has a significant negative impact on the proportion of the company's inventory. When the geographic proximity of customers is higher, the proportion of inventory is smaller. In the second column, the coefficient of CGP1 is 1.0731, which is significant at the level of $1 \%$, which proves the significant positive correlation between customer geographic proximity and inventory turnover. That is, the higher the geographical proximity of the customer, the faster the enterprise inventory turnover and the higher the inventory turnover rate. Similarly, in the regression with CGP2 as the independent variable, the coefficient of CGP2 is significant at the level of $1 \%$, indicating that there is a significant positive correlation between the geographical proximity of the customer and the inventory management level of the enterprise. The higher the proximity, the lower the inventory ratio of the enterprise and the higher the inventory turnover rate.

In this paper, the enterprise as a supplier of the products know more about the products, but the needs of customers are relatively unknown. Customers are more clear about their own needs, not clear about the products of suppliers, which has formed information asymmetry. Asymmetric information brings transaction costs. Transaction costs include search cost, information cost, bargaining cost and decision cost. When the geographical distance between the enterprise and the customer is far away, the degree of information asymmetry increases: it is relatively difficult for the enterprise to understand the customer demand or the customer to know the products of the enterprise, and the cost of searching information for the enterprise also rise accordingly. When the geographical proximity between the enterprise and customer is high, the customer can know the information of the product at any time, the enterprise can seize the customer's demand, get the customer's feedback about the product in time, adjust purchasing and production plan according to the change of customer demand, reduce inventory cost. Enterprises with similar geographical position and customers can establish exclusive information communication system through timely information communication and mutual running-in communication, and gradually achieve "Just in Time" and "zero inventory" production.

\section{Conclusion}

This paper uses the manually collected data of the top five customers of China's manufacturing enterprises to examine the impact of customer geographic proximity on inventory management level of manufacturing enterprises. The results show that there is a positive relation between the geographic proximity and inventory management level: the greater the geography proximity of customers, the lower the proportion of inventory, the higher the inventory turnover rate.

\section{Acknowledgements}

Three years of graduate life is about to end, but for my life is just a comma. This 
paper is a summary of my three years of learning results. I have used the knowledge and delved into the knowledge that I have never touched. I have given myself, parents, teachers, and school a satisfaction. Answer sheet.

\section{Conflicts of Interest}

The author declares no conflicts of interest regarding the publication of this paper.

\section{References}

[1] McKinsey, C. (2008) Managing Global Supply Chains. The McKinsey Quarterly, 2-9.

[2] Dai, Y.K. and Lin, S. (2017) Interest Rate Fluctuation, Financing Constraints and Inventory Investment: Evidence from Chinese Manufacturing Enterprises. Journal of Financial Research, 4, 95-111.

[3] Bai, Y.X., Yan, M.Y. and Tan, W.H. (2013) Institutional Environment, Inventory Management and Company Value-Evidence from State-Owned Listed Companies in Manufacturing Industries. Contemporary Accounting Review, 1, 28-44.

[4] Li, H. and Li, Z.G. (2009) The Impact of Transportation Infrastructure Investment on Enterprise Inventory-An Empirical Study Based on Panel Data of China's Manufacturing Enterprises. Management World, 8, 73-80.

[5] Rao, P.G., Yue, H. and Jiang, G.H. (2016) Inflation Expectation and Enterprise Inventory Adjustment Behavior. China Economic Quarterly, 15, 499-526.

[6] Shan, J. and Zhu, K.J. (2013) Inventory Management in China: An Empirical Study. Production and Operation Management, 22, 302-313.

https://doi.org/10.1111/j.1937-5956.2012.01320.x

[7] Zhao, Q.W., Huang, Z.Z. and Bu, X.Z. (2010) Empirical Study on the Influencing Factors of Domestic Retail Enterprise Inventory Level-Based on Panel Data of Listed Companies in Shanghai and Shenzhen Retail Industry. Journal of Industrial Engineering and Engineering, 2, 48-55.

[8] Demeter, K. and Matyusz, Z. (2011) The Impact of Lean Practices on Inventory Turnover. International Journal of Production Economics, 133, 154-163. https://doi.org/10.1016/j.ijpe.2009.10.031

[9] Giroud, X. (2013) Proximity and Investment: Evidence from Plant-Level Data. The Quarterly Journal of Economics, 128, 861-915. https://doi.org/10.1093/qje/qjs073

[10] Cohen, D. and Li, B. (2016) Customer-Base Concentration, Profitability and the Information Environment: The U.S. Government as a Major Customer. Working Paper, University of Texas at Dallas.

[11] Raman, K. and Shahrur, H. (2008) Relationship-Specific Investments and Earnings Management: Evidence on Corporate Suppliers and Customers. The Accounting Review, 83, 1041-1081. https://doi.org/10.2308/accr.2008.83.4.1041

[12] Krishnan, G.V., Lee, H.S. and Patatoukas, P.N. (2014) Major Customer Dependency: Implications for Audit Pricing and Quality. Social Science Electronic Publishing. http://dx.doi.org/10.2139/ssrn.2440009

[13] Campello, M. and Gao, J. (2017) Customer Concentration and Loan Contract Terms. Journal of Financial Economics, 123, 108-136. https://doi.org/10.1016/j.jfineco.2016.03.010

[14] Dan, D., Judd, J.S. and Serfling, M. (2016) Customer Concentration Risk and the 
Cost of Equity Capital. Journal of Accounting and Economics, 61, 23-48. https://doi.org/10.1016/j.jacceco.2015.03.005

[15] Huang, H.H., Lobo, G.J. and Wang, C. (2016) Customer Concentration and Corporate Tax Avoidance. Journal of Banking and Finance, 72, 184-200. https://doi.org/10.1016/j.jbankfin.2016.07.018

[16] Knechel, W., Salterio, S. and Ballou, B. (2007) Auditing: Assurance and Risk. South-Western College Publishing.

[17] Huang, F.G., Peng, T. and Shao, Y. (2014) How Geographical Distance Affects Venture Capital's Investment in New Enterprises. Nankai Business Review, 17, 83-95.

[18] John, K., Knyazeva, A. and Knyazeva, D. (2011) Does Geography Matter? Firm Location and Corporate Payout Policy. Journal of Financial Economics, 101, 533-551. https://doi.org/10.1016/j.jfineco.2011.03.014

[19] Yang, J.F., Lu, J.Q. and Wang, W.H. (2017) Research on the Integration Effect of the Combination of Accounting Firms in China-From the Perspective of Comparability of Accounting Information. Accounting Research, 6, 3-10 + 96.

[20] Li, H. and Tang, L.M. (2015) Transportation Infrastructure Investment, Spatial Spillover Effect and Enterprise Inventory. Management World, 4, 126-136.

[21] Mei, F. (2013) On the Implementation of Zero Inventory Management. Communication of Finance and Accounting, 2, 123-124.

[22] Joseph, P.C. and Christian, H. (2001) Buyer-Supplier Relationships and Customer Firm Costs. Journal of Marketing, 65, 29-43. https://doi.org/10.1509/jmkg.65.1.29.18136

[23] Jia, N. and Mayer, K.J. (2017) Political Hazards and Firms' Geographic Concentration. Strategic Management Journal, 38, 203-231. https://doi.org/10.1002/smj.2474

[24] Li, Y.P. (2017) Customer Relationship Trading and Manufacturing Enterprise Performance: Impact Effect and Mechanism. Macroeconomic, 2, 130-141.

[25] Ellison, G. and Glaeser, E. (1997) Geographic Concentration in U.S. Manufacturing Industries: A Dartboard Approach. Journal of Political Economy, 105, 889-927. https://doi.org/10.1086/262098

[26] Guariglia, A. and Mateut, S. (2010) Inventory Investment, Global Engagement, and Financial Constraints in the UK: Evidence from Micro Data. Journal of Macroeconomic, 32, 239-250. https://doi.org/10.1016/j.jmacro.2009.03.001

[27] Jones, C.S. and Tuzel, S. (2013) Inventory Investment and the Cost of Capital. Journal of Financial Economics, 107, 557-579. https://doi.org/10.1016/j.jfineco.2012.09.001

[28] Carpenter, R., Fazzari, S. and Petersen, B. (1998) Financing Constraints and Inventory Investment: A Comparative Study with High-Frequency Panel Data. Review of Economics and Statistics, 80, 513-519. https://doi.org/10.1162/003465398557799 